\title{
Organized Retailing in Context with Amalgamation of Small Firms in Saudi Arabia
}

\author{
Mohammad Naquibur Rahman \\ Department of Marketing, College of Business, Umm Al Qura University, Makkah Al Mukarrmah, Saudi Arabia
}

Email address:

uqu.naquib@gmail.com,mnrahman@uqu.edu.sa

\section{To cite this article:}

Mohammad Naquibur Rahman. Organized Retailing in Context with Amalgamation of Small Firms in Saudi Arabia. International Journal of Economics, Finance and Management Sciences. Vol. 3, No. 5, 2015, pp. 583-593. doi: 10.11648/j.ijefm.20150305.30

\begin{abstract}
The purpose of present study systematically brings into focus the prospects of organized retailing in Saudi Arabia and its growth drivers as Baquala (small store) turning into small stores to supermarket and hypermarkets. The present dissertation is a systematic and comprehensive analysis and objective study of organized retailing in KSA and its outcome analysis thereof. The basic purpose of the present study is to find out and develop a co-relation taking place between organized retailing in KSA and growth drivers thereof. The GCC retail industry is poised for a healthy growth in Middle East and KSA. It also points out at geographical dispersions of market potential for varying class of customers. It aims at observing growth of Saudi Arabian retail market like Carrefour, Panda Bin Dawood, Al-Marai, Sadafco and Savola etc. The present study further intends to estimate share of organized retail in KSA. The dissertation further studies KSA growth drivers accelerating retail business identified as an organized retailing: for example such growth drivers like growing population, online retailing, retail demand, malls and super/hypermarket and religious tourism that gives boost to organize retailing in KSA. The present study points out at new emerging trends and retail space after the inflow of organized retailing in KSA. In order to study a comprehensive organized retailing in KSA and growth drivers operative therein, as the survey research methodology has been applied to study research objectives. Discussion in organized retailing points out at various factors like socio-economic, changing income profile, changing role of women, age factors and finally dynamic role of banking system - make a dynamic impact on organized retailing in KSA as well as growth drivers as shape, form and quality need to be maintained and modernize in terms growing organize retailing in KSA.
\end{abstract}

Keywords: Organized Retailing, Growth Drivers, Retail Industry, Emerging Trends, Amalgamation of Firms

\section{Introduction}

Organized retailing in Saudi Arabia is a new planned economic phenomenon. Therefore, it's necessary to make an objective to study the growth drivers and outcome analysis. As Saudi universe has turned into a global and cross cultural market, the structure, policy and form of business strategy have reciprocally changed. The transformation of cross cultural market needs to be analyzed the comprehensive areas in terms of organized retailing, growth drivers as well as outcome analysis. Al Jazirah capital report $2012^{1}$ claims that past few years back the Saudi Arabian Retail sector changed from a traditional market comprising unorganized stores like Baquala to organized large scale supermarket, hypermarket and malls with competitive global brands. Presently most of

1 Al Jazirah Capital Report 2012 the international retail chains as well as local player operate in KSAs retail market e.g. McDonald, KFC, Pizza Hut, Domino's Pizza, Starbucks, Pepsi, Coca Cola, Zara stores, IKEA, Mango, Subway and Carrefour hypermarket. The entry of these retail chains made Saudi Arabia's retail sector highly competitive. As such the Middle East retail sector plan for 2020 classifies Saudi Arabia and UAE into potential and dynamic retail. The two leading markets i.e. Saudi Arabia and UAE have emerged as dominant potential market within the retail landscape. A large expatriate population living in Saudi Arabia and UAE are concerned with majority of regions retail investment- create a new scope of sales and distribution Gilbert David ${ }^{2}$ in this context rightly mentioned in his book Retail Marketing ( 2003) page 2 that the retailing is not integral part of economic structure but at the same time

2 Gilbert David mentioned in his book Retail Marketing (page 2)Pearson publication 2003 
it is developed by particular and distinct way of life emerged and identified in KSA.

The vital factor of retail sector can be identified from its contribution to gross domestic production. The GCC retail industry has emerged as the most potential market in the GCC universe: identifies as one of the fastest growing sector in Middle East ${ }^{3}$ as mentioned in GRDI report 2015. As such the data mentioned below shows that the GCC retail industry is the second largest sector in Oil - GCC region. It is considered being the most favorable means of diversification. Therefore, it can logically be argued that the Saudi retail sector hyper markets and malls - have reciprocally replaced the traditional and old fashioned market spread all over the kingdom of Saudi Arabia. Therefore, the GCC retail industry attracts a large part of buyers as well as consumers. Seeing the things from this angle, the growth of Saudi Arabian organized retail markets with multidimensional business groups are given priority in the kingdom at least for a decade. Such hypermarkets can be identified as new business innovation like Carrefour, Bind wood, Savola, Al Marai, Al Saafi, Sadafco, STC, Unilever, Pepsi Cola, Coca Cola, and Aujan Soft drinks. In this regard finding of Mohammad AlAjlan 4 Head commercial committee, Riyadh chamber of Commerce and industry significantly argued that the retail sector is divided into two: organized and non organized sectors. Furthermore, he added that the big companies well known commercial centers that can be known as practicing business; on the other hand, the non-organized sector business practices are putting more economic pressure on buyers as well as on the kingdom. In addition, the economic growth rate along with impressive GDP growth and decreasing rate of unemployment help in increasing consumer disposable income. Consumers' demand of delivering services at home brings further appreciation and satisfaction as well as preference. Thus, it can be logically argued that services and facilities provided by growing organized retailing in KSA do not have only mixed positive impact on growth drivers but also on outcome analysis. Therefore, it can be logically concluded that the growing demand of GCC retail industry helps customers to increase the buying capacity of multiplicity of products in the retail market of KSA.

The retail business was not much in vogue in KSA in early 2000; a new trend of retail scenario emerged in KSA market characterized by major shift in options and preferences. Therefore, a shift from Baquala (small grocery store) to supermarket and hypermarkets is specifically being experienced in the retail industry. Therefore, a radical change in attitude, preferences and options of the new buyers and young generation became centre of attraction of supermarkets, hypermarkets and malls. A new trend of marketing by virtue of amalgamation of companies and firms provided a better and a larger comprehensive market giving feed back to new consumers/ buyers in KSA. From this

3 GRDI report 2015

4 Head commercial committee, Riyadh chamber of Commerce perspective, growth of organized retail has been mentioned as below.

It is worth mentioning that the data published by $\mathrm{GRDI}^{5}$ 2015 page 14 the retail sales volume of KSA is above $\$ 103$ billion as $7.7 \%$ CAGR: retail space grew $5.6 \%$ to 2.1 million square meter and sales increased by $6.4 \%$ where as organized retailing has increased up to $18 \%$ CAGR (compound average growth rate): for period no less than five - accounts 370 Billion (FMCG) sales in 2010.

\section{Literature Review}

\subsection{Overall Retail Scenario in $\mathrm{KSA}$}

Overall a retail prospect in KSA is promising attracting and inviting companies to invest capital in KSA. As the GDP growth - shows high prospects of GDP growth, Rahman, Mohammad Naquib ${ }^{6}$ mentioned in his research paper, renowned economist Steve Keen during the interviewed on the BBC's Hard Talk, November 24, 2011 the European Market is in the face of economic recession on the one hand; the Saudi Arabian economy goes on to be robust and unaffected by recession and inflationary trends affecting the supremacy of Euro and Dollar. The recession put the retail industry under slow growth. However, Middle-East is least affected zone from economic crisis.

David Gilbert rightly observes that GDP is linked with significant proportion of economy in a particular universe. The data mentioned by David Gilbert points out that as a result of enhancement in wages particularly in public sector, household expenditure reciprocally got a boost in GDP growth. In 2013, the country's GDP (constant price) grew at $4.0 \% \mathrm{y}-\mathrm{o}-\mathrm{y}$ due to government spending and revenue from the oil sector. Saudi Arabia continues to rely significantly on its hydrocarbon sector, which contributed $47.4 \%$ to its nominal GDP in 2013.

As a result, the positive GDP would ultimately give boost to food sector. As some of the European countries are passing through economic recession, Saudi Arabian economy goes on to sustain and survive in the global market. The value of Saudi Riyal goes on to sustain in the international market in comparison with Euro \& Dollar comparatively. We cannot escape from the reality that the inflationary trends is prevailing in the western world. Therefore, both the Saudi and European countries find a favorable pasture of sustaining their retail business.

The overall retail sales growth in Saudi Arabia in 2013 is estimated at $5.7 \%$ to US\$ 92.6 billion, $16.1 \%$ of its GD (see Exhibit 4). The volume growth was however slowed down during the past two years due to departure of millions of expatriates. The retail sector of Food remains the largest retail sub-sector in the kingdom. Saudi Arabia's consumer goods market was valued at US\$ 37.8 billion in 2013. The

5 GRDI Report 2015

6 Consumer Behavior and Retail Market Consumerism In KSA, International Journal of Scientific \& Engineering Research, France Volume 3,Issue 11, November-2012 1 ISSN 2229-5518 
retail sector in KSA as a result has undeniably turned into a global market. With increasing number of global, brands, promoters all the factors instrumental in growing retail business in KSA- has enabled Saudi Riyal to maintain its value and worth.

As inflationary trends in the European countries are on rise, the basic aim of the Saudi economic think-tank is to maintain the worth of Saudi Riyal, where Dollar \& Euro are facing economic recession. The basic goal and objective of this dissertation is to analyze and find out that affects globalization of retail sector. That is why rapid transformation and amalgamation of smaller firms into sizeable industry is providing a good platform for domestic industry as well as investment opportunity for foreign businessmen. It is worth mentioning that new strategies need to be planned and implemented taking into account new emerging market and arenas in KSA.

Retail scenario in KSA is a new phenomenon attracting a large number of consumers of various classes and categories. A worldwide retailing is passing through a process of evolution. Retail sector as a result has been transformed by a global phenomenon with growing number of global products, bank, new business technique and developers. However there are many obstacles to the growth and implementation in the retail market. Many factors, however, affect the retail sector including Saudi Arabia, UAE and over all GCC. Rapid transformation of new industries into a larger industries and new ideas, innovations as well as strategies are playing a pivotal role in bring a shift new global business models.

As a result of amalgamation of smaller firms into larger firms is taking place with rapid growth e.g. Coca Cola took over the Aujan Soft drinks; Al-Marai to Riyadh Laben; similarly Western bakeries, International Baking service, Hadco have passed through the same stages of amalgamation. Savola took over Geant hypermarket and Giant hypermarket.

There is a need to take reference to the special SAMA (Saudi Arabian Monetary Authority) that has calculated the wholesale and retail sector accounting to $21.5 \mathrm{M}$ in KSA.

The retail sector employees is over 10 percent of the national workforce, but characterized by a high degree of fragmentation with around five million outlets, $96 \%$ of them are very small with an area of less than $50 \mathrm{~m}$. As Philip Kotler mentioned the retail universe doubled between 1986 and 2006 and the number of outlets per 1000 people at all India level increased from 4.9 in 1998 to $14.8 \%$ in 2006 , because of their small size. Indian retailers have very bargaining power with manufacturers and perform only a few of the flows in marketing channels unlike in the case of retailer in developed countries ${ }^{7}$.

A major move can be seen very clearly here in retail market structure that Saudi Retail is the largest in GCC representing $42 \%$ of the council's market size, followed by the UAE (29\%) and Qatar (11\%). The retail market of KSA has developed over the period of time, but the industry has

7 Principles of Marketing, Philip Kotler,15th edition, pg 396 witnessed the key growth drivers in the past 15 years. According to SAMA $^{8}$ (Saudi Arabian Monetary Agency) 2011 annual report, as Saudi population was recorded at $27.1 \mathrm{mn}$ in 2010 where significant portion approximately $47 \%$ of total population aged between 15 to 39 . As IMF mentioned that the KSA population will increase at 2010-2015 CAGR of $1.4 .8 \%$ and will reach to $29.02 \mathrm{mn}$ in 2015 . The present data published in 2012 indicate that the Saudi Arabia is a major retail market. In the GCC countries with market size of USD 69.0bn- in 2011, the business is expected to reach at USD 76bn - USD 78bn in 2012, according to EIU \& Jones Lang La Salle.

Director Commercial Operation ${ }^{9}$ of Sadafco milk company KSA claims those six main indicators as below mentioned:

1. Price

2. Promotion

3. Sales personnel

4. Quality of merchandising

5. Advertising and

6. Convenience services

All above indicators play a key role for retailers in selecting and opting the type of retail formats that may help them to cope-up with changing options and preferences of consumers. In a situation where retail market has the large prospect to develop the real estate market is supposed to grow up from positive economic indication as mentioned by data. Indicators like oil price and over all kingdoms GDP which are supposed to grow up by $7.3 \%$ in 2014 , whereas the previous forecast of GDP was $6.9 \%$.The prevailing financial climate also offers a strong opportunity for organization to strengthen their reserves and structure long term growth plans.

According to A.T. Kearny's 2014 Global Retail Development Index (GRDI), KSA retail market is ranked as the $16^{\text {th }}$ most attractive retail market around the global in terms of-

a. Investment opportunities at present and

b. Future growth prospects of organized retailing of KSA As compared to GRDI repot of 2014 Vs $2015^{10}$ the retail sector of Saudi Arabia is $17^{\text {th }}$ position and it still reflecting fast growing trends. Retail space is grew by 5.6 percent to 2.1 million square meters 2014 as well as sales increased by $6.4 \%$.

\subsection{Growth Drivers Sustain KSA Retailing}

Domestic demand is one of the key growth drivers persisting and promoting KSA organized retail sector. As per data collected during last five years, it can be noticed that the per capita retail sale has grown up to $9 \%$, which is expected to grow up SR 13243, which comes up USD 3532 in 2011. Growth in per capita retail has been noted higher than that of developed countries like US, Germany and Japan, which is

8 Saudi Arabian Monetary Agency

9 John Director Commercial Sadafco mentioned at Umm Al- Qura University, march 18,2015

10GRDI Global Retail Development Index Report 2015 
lower that China's 23.2\% annual increase over 2006-2011. On the other hand KSA's real sales have been found to be lower i.e.45- 75 in 2014 as compared with developed countries. Hence, it can logically be argued that KSA is promising hub for growth in per capita retail sales. As data received by survey research method, there are many significant growth drivers which enhance retailing Viz.

- Growing Population
- Retail Demand

- Online retailing

- Super / hypermarkets and Malls emerging as new avenues of retail business and entertainment

- Religious tourism

- Emerging Trends

- Retail Space: a new hub competitive market

Table 1. GRDI Ranking 2014: Comparison with GCC Countries On Different GRDI Parameters.

\begin{tabular}{llllll}
\hline Countries & $\begin{array}{l}\text { Market attractiveness } \\
\text { (0:Low 100:High) }\end{array}$ & $\begin{array}{l}\text { Country Risk } \\
\text { (0:Low 100:High) }\end{array}$ & $\begin{array}{l}\text { Market Saturation } \\
\text { (0:Low 100:High) }\end{array}$ & $\begin{array}{l}\text { Time Pressure } \\
\text { (0:Low 100:High) }\end{array}$ & $\begin{array}{l}\text { GRDI Score } \\
\text { 2014 Rank }\end{array}$ \\
\hline UAE & 98.5 & 82.3 & 17.5 & 43.8 & 40.5 \\
Kuwait & 78.5 & 72.6 & 32.9 & 31.7 & 54.0 \\
Saudi Arabia & 72.3 & 67.3 & 29.5 & 27.4 & 4 \\
Oman & 75.1 & 79.1 & 27.0 & 11.1 & 49.1 \\
\hline
\end{tabular}

Source: A.T. Kearney GRDI 2014

Note: $\uparrow$ Indicates increase in ranking from the previous

$\longleftrightarrow$ Indicate same rank as in the previous

Table No 2. GRDI Global Retail Development Index Report 2015.

\begin{tabular}{|c|c|c|c|c|c|c|c|c|c|}
\hline $\begin{array}{l}\text { 2015- } \\
\text { Rank }\end{array}$ & Country & $\begin{array}{l}\text { Market } \\
\text { attractiveness } \\
25 \%\end{array}$ & $\begin{array}{l}\text { Country } \\
\text { Risk } \\
(25 \%) \\
\end{array}$ & $\begin{array}{l}\text { Market } \\
\text { Saturation } \\
(25 \%)\end{array}$ & $\begin{array}{l}\text { Time } \\
\text { Pressure } \\
(\mathbf{2 5 \%}) \\
\end{array}$ & $\begin{array}{l}\text { GRDI } \\
\text { Score }\end{array}$ & $\begin{array}{l}\text { Rank } \\
\text { Compared } \\
\text { To } 2014 \\
\end{array}$ & $\begin{array}{l}\text { Population } \\
\text { In million }\end{array}$ & $\begin{array}{l}\text { GDP per } \\
\text { Capita } \\
\text { (thousand) }\end{array}$ \\
\hline 1 & China & 66.7 & 55.7 & 42.3 & 96.6 & 65.3 & 1 & 1,364 & 13 \\
\hline 2 & Uruguay & 93.3 & 60.4 & 68.0 & 38.9 & 65.1 & 1 & 3 & 20 \\
\hline 3 & Chile & 98.2 & 100.0 & 13.0 & 37.9 & 62.3 & 2 & 18 & 23 \\
\hline 4 & Qatar & 100.0 & 89.4 & 34.3 & 12.8 & 59.1 & N/A & 2 & 144 \\
\hline 5 & Mongolia & 22.4 & 19.9 & 93.1 & 100.0 & 58.8 & N/A & 3 & 10 \\
\hline 7 & UAE & 97.6 & 84.0 & 16.5 & 33.9 & 58.0 & 3 & 9 & 65 \\
\hline 8 & Brazil & 98.0 & 60.4 & 45.2 & 28.0 & 57.9 & 3 & 203 & 15 \\
\hline 9 & Malaysia & 75.6 & 68.8 & 29.3 & 52.7 & 56.6 & & 30 & 25 \\
\hline 10 & Armenia & 35.4 & 37.1 & 82.1 & 66.3 & 55.2 & 4 & 3 & 7 \\
\hline 11 & Turkey & 83.1 & 48.1 & 40.2 & 44.8 & 54.1 & & 77 & 20 \\
\hline 12 & Indonesia & 50.6 & 35.5 & 55.1 & 65.9 & 51.8 & 3 & 251 & 10 \\
\hline 13 & Kazakhstan & 49.6 & 34.2 & 72.5 & 50.7 & 51.8 & -3 & 17 & 34 \\
\hline 15 & India & 30.5 & 39.8 & 75.7 & 58.5 & 51.1 & +5 & 1,296 & 6 \\
\hline 16 & Peru & 48.9 & 43.9 & 58.6 & 51.8 & 50.8 & -3 & 31 & 12 \\
\hline 17 & Saudi Arabia & 78.6 & 64.4 & 30.4 & 27.0 & 50.1 & -1 & 31 & 54 \\
\hline 18 & Botswana & 49.2 & 62.5 & 33.3 & 54.2 & 49.8 & +8 & 2 & 16 \\
\hline 19 & Panama & 62.3 & 46.8 & 49.7 & 37.6 & 49.1 & -5 & 4 & 20 \\
\hline 20 & Colombia & 55.6 & 49.3 & 52.0 & 39.1 & 49.0 & +1 & 48 & 13 \\
\hline 21 & Russia & 94.9 & 28.4 & 24.5 & 46.6 & 48.6 & -9 & 144 & 25 \\
\hline 22 & Azerbaijan & 33.9 & 26.9 & 82.4 & 46.8 & 47.5 & +8 & 10 & 18 \\
\hline 23 & Nigeria & 19.6 & 8.3 & 94.0 & 66.5 & 47.1 & -4 & 178 & 6 \\
\hline 24 & Philippines & 39.6 & 36.0 & 51.6 & 60.7 & 47.0 & -1 & 100 & 7 \\
\hline 25 & Jordan & 51.1 & 35.5 & 64.2 & 36.8 & 46.9 & -3 & 8 & 12 \\
\hline 26 & Oman & 75.0 & 77.3 & 24.9 & 9.8 & 46.7 & -9 & 4 & 44 \\
\hline 27 & Kuwait & 81.0 & 68.1 & 33.2 & 0.0 & 45.6 & $-19 *$ & 4 & 71 \\
\hline 28 & Costa Rica & 66.9 & 49.2 & 38.7 & 5.1 & 45.0 & -4 & 5 & 15 \\
\hline 29 & Mexico & $82 . .5$ & 56.1 & 0.2 & 38.8 & 44.4 & -4 & 120 & 18 \\
\hline
\end{tabular}

Notes: PPP is purchasing power parity. For an interview map of the GRDI top 30 countries, www.atkearny.com//consumer.products-retail/global-retail-development-index

*The significant decline in kuwait's position in GRDI is partially due to a change in country-specific data sources p-17 GRDI -2015

Source: Economist Intelligence Unit, Euromoney, IMF, Planet Retail, Population Reference Bureau, World Bank, World Economic Forum; A.T. Kearney Analysis 


\subsection{Growing Population in $\mathrm{KSA}$}

Prefer to opt for organized retail sales, retail sales can preferably be related to increasing disposable income and growth witness by new growing business that reflects from the data mentioned by IMF (International Monetary Fund) ${ }^{11}$. The kingdom population is supposed to increase 2010 to 2015 CAGR of $1.4 \%$ which is further expected to grow up to $31.0 \mathrm{mn}$ in $201533.1 \mathrm{mn}$ as forecasted for 2018. Based on the above data, it can be realized that the youth of 15-39 will continue to dominate the remaining population up to 2015 . As the data shown by $\mathrm{IMF}^{12}$, it can logically be argued that KSA real GDP is expected to grow 6\% in 2012: $4.3 \%$ in 2013 , and $4.3 \%$ in 2015 .

\subsection{Online Retailing}

Barry Berman \& R Joels have studied online retailing ${ }^{13}$ which points out the growing trends of online retailing in KSA

1. Web design/interaction: includes all elements customers experiments at website

a. Website Information search

b. Order processing

c. Shipment \& tracking

d. Product Availability

e. Price offering

2. Fulfillment and Reliability: Customer received product as displayed on website

3. Customer Service: helpful, responsive services, respond customer enquiry quickly either during or after sale and service

4. Security/Privacy: The security of credit card payments and privacy of share information during or after the sales.

Online retailing is getting popular day by day in KSA. There are many factors which establish relation between consumers and products: between retailers and users on the global plane. Online retailing attracts customers to store, mini-market, and super/hypermarket expectation of customer. That is why the number of users has increased and short up from $5 \%$ in 2001 to $41 \% 2010$, which is ultimately expected to come up 51.55 in 2015 . What is worth mentioning is that is getting popularity in women and single men taking into account Kingdom's social structure.

\subsection{Retail Demand}

Having taking into consideration the nature and the factors of growth drivers' retail demand has simultaneously increased. Retail demand has reached new dimensions of popularity among women and single men. Therefore, it can be said that growth in discretionary spending has given rise

11 International Monetary Fund

12 IMF October 2014 WTTC Alpen Capital

13 Barry Barman and Joels Evans,2010 to uptrend demand for cloth dressing like Splash, mango and arrow. KSA at present has a considerable retail demand of clothing, accessories, grocery commodities which are indicative of increasing retail demand in Saudi Arabia. Therefore, growth in retail demand is directly proportional to the supply with floor space expected to increase 4.2 million in 2010 to $5.4 \mathrm{mn}$ by 2015 .

\subsection{Religious and Historical Landscape}

Influx of religious tourist particularly on the religious occasion of Hajj and Umrrah is the second largest contribution to Saudi Arabia GDP. Taking into account of the data exhibited by KSA Government about 12 million tourist pay visit to KSA per year. Mohammad Naquibur Rahman mentioned in his research paper ${ }^{14}$ that Saudi Arabia is getting benefits of tourist for Hajj and Hajj Umrrah. It is playing a pivotal role in consolidating its economic and social position vibrant. Lots of malls are being made to attract the customers to boost its retails sectors. This is giving Saudi Arabia a unique social and well as economical leverage in the members of gulf counties. This contributes in generating revenue for the country and well it is giving big for retail market.

According to the conference held in Umm Al- Qura university 26-28 May, 2012 Saudi Arabia is expected to see 9.3 million new visitors between 2012 and 2015, where both Mecca and Madinah contribute $6 \%$ of the total gross leasable (GLA) in KSA. The GLA in Saudi Arabia is supposed to emerge as the biggest retail market after Riyadh and Jeddah. Taking into account the data given below the number of tourist is expected to increase up to $17 \mathrm{mn}$ by $2025^{15}$. At present $0.24 \mathrm{mn}$ miles are under construction: $20 \%$ of total under construction in Makkah and Madinah.

Table 2. Inbound Tourist Trips by Purpose of Visit and Quarter.

\begin{tabular}{llllllr}
\hline $\begin{array}{l}\text { Purpose } \\
\text { of Visit }\end{array}$ & $\begin{array}{l}\text { First } \\
\text { Quarter }\end{array}$ & $\begin{array}{l}\text { Second } \\
\text { Quarter }\end{array}$ & $\begin{array}{l}\text { Third } \\
\text { Quarter }\end{array}$ & $\begin{array}{l}\text { Fourth } \\
\text { Quarter }\end{array}$ & Total & $\begin{array}{l}\text { Market } \\
\text { Share \% }\end{array}$ \\
\hline Religious & 490974 & 707492 & 1574612 & 2094308 & 4867387 & $44.9 \%$ \\
\hline
\end{tabular}

Source: Hajj Institute, Umm Al Qura University, 2014

\subsection{New Emerging Trends}

There are new emerging trends, which enhance organized retail sector widening its reach beyond Jeddah and Riyadh. Compared to that of UAE, GCCs is the second largest retail market. It can be seen that it accounts for $78 \%$ of total GLA.

\subsection{Retail Space}

The data exhibited in table 3 show retail space is getting highly competitive and its grew by $5.6 \%$ to 2.1 million square meters in 2014 as GRDI $2015^{16}$. It has been noticed

14 International Journal of Business and Economic Development V-2 Number 1 March 2014 p 101-112

15 The Al Jazirah capital 2012

16 GRDI : Global Retail Development Index 2015 page -15 
that the universe of retail of Saudi Arabia has basically risen out from conventional market (Baquaala) to organized retail shopping malls/ hypermarkets emerging as the largest global brands. Mohammad Naquibur Rahman mentioned in his research paper ${ }^{17}$ In this regard top five firms namely, Savola Group, Carrefour, and Fawaz Abdul Aziz Al Hokier hold $11 \%$ of market share, lower viz-viz developed markets like UK in which a top five competitors hold $59 \%$ market share. The total number of estimated retail outlets in the country stood at 41,000 in 2013.

Table No 3. Top five retailers in $K S A^{18}$.

\begin{tabular}{lllllll}
\hline Company & Store & $\begin{array}{l}\text { Projection } \\
\text { by 2016 }\end{array}$ & $\begin{array}{l}\text { Sales } \\
\text { Area } \\
\text { (m) }\end{array}$ & $\begin{array}{l}\text { Average } \\
\text { Sales } \\
\text { Area } \\
\text { (m) }\end{array}$ & $\begin{array}{l}\text { Grocery } \\
\text { Banner } \\
\text { Sales } \\
\text { (USD) }\end{array}$ & $\begin{array}{l}\text { Market } \\
\text { Share\% }\end{array}$ \\
\hline Panda & 144 & 170 & 628500 & 4365 & 1742 & 4.2 \\
Bindawood & 30 & 40 & 205000 & 6833 & 929 & 2.3 \\
Al Othaim & 108 & 130 & 162441 & 1504 & 879 & 2.0 \\
Carrefour & 17 & 25 & 107000 & 6294 & 683 & 1.7 \\
Farm & 43 & 50 & 115850 & 2694 & 327 & 0.8 \\
Total & 342 & 415 & 1218790 & 4344 & 4560 & 11.9 \\
\hline
\end{tabular}

Table 4. Amalgamation of Companies in $K S A^{19}$.

\begin{tabular}{|c|c|c|c|}
\hline Acquired by & Target Company & Year & $\begin{array}{l}\text { Deal Value } \\
\text { USD } \\
\text { Million } \\
\end{array}$ \\
\hline Savola Group & $\begin{array}{l}\text { Al Azizia Panda United } \\
\text { Limited, }\end{array}$ & 2010 & 295.7 \\
\hline Savola Group & $\begin{array}{l}\text { Geant Supermarket\& } \\
\text { hypermarket of KSA }\end{array}$ & 2009 & 117.3 \\
\hline Savola Group & $\begin{array}{l}\text { Gaiant Supermarket of } \\
\text { KSA }\end{array}$ & 2009 & NA \\
\hline $\begin{array}{l}\text { Saudi } \\
\text { International } \\
\text { Trading Co Ltd }\end{array}$ & $\begin{array}{l}\text { Al Dawaa Medical } \\
\text { Services Co Ltd }\end{array}$ & 2009 & 26.7 \\
\hline $\begin{array}{l}\text { Fawaz AbdulAziz } \\
\text { Al Hokair \& Co }\end{array}$ & 42 Shopping Outlet & 2014 & 102.1 \\
\hline Fawaz Abdul Aziz & Retail Group Jordan & 2010 & 7.2 \\
\hline Al Hokair \& Co & Retail group Egypt & 2010 & 5.6 \\
\hline $\begin{array}{l}\text { Al-Marai } \\
\text { Company }\end{array}$ & Western Bakeries Ltd & 2007 & NA \\
\hline $\begin{array}{l}\text { Al-Marai } \\
\text { Company }\end{array}$ & $\begin{array}{l}\text { International Baking } \\
\text { Services }\end{array}$ & 2007 & NA \\
\hline $\begin{array}{l}\text { Al-Marai } \\
\text { Company }\end{array}$ & $\begin{array}{l}\text { HADCO (Hail Agro } \\
\text { Development Company) }\end{array}$ & 2008 & NA \\
\hline AlMarai Company & Riyadh Laben & 2003 & NA \\
\hline Coca Cola & $\begin{array}{l}\text { Aujan Soft Drink } \\
\text { Indusries ( ASDI) }\end{array}$ & 2010 & 980 \\
\hline
\end{tabular}

Source: Zawya Bloomberg 2015

In order to organize the retail sector of KSA, there are many factors contributed globally including Saudi Arabia. It includes the rapid transformation of the industry as a whole; the new idea innovated and strategies enable the situation for paving the way into emerging markets and shifting new

17 International Journal of Business and Economic Development Vol. 2 Number 1 March 2014, page 102-113

18 Source: Economist Intelligence Unit, Feb 2012

19 Thompson database, Zawya 2012 business models globally. Furthermore, it can be seen very clearly in the kingdom that the amalgamation of the companies is going very fast e.g. Coca cola has taken over the Aujan Soft drink company, Al-Marai has taken over to Riyadh Laben, Western Bakeries, International Baking services, HADCO etc. Having taken into consideration the fragmented nature of KSA retail sector and rising emerging popularity of organized retail, amalgamation of smaller firms into a larger considerable firms are likely to capture comparative larger market share as the data mentioned below. Furthermore, merger, acquisition and amalgamation of firms played a very important role in organizing Saudi Arabian retail market as mentioned in table number 5 .

\section{Objective of Study}

The basic objective to organize retail in KSA is to provide a quantitative analysis of both past and future trends existing in retail marketing. Methodology: research survey method applied in this context provides insight, trends, forecast in market trends, which further help in analyzing. In fact, the real shape and form of retail market chalking out, proper strategy with a view to meeting with emerging challenges.

- To identify and locate the leading organized retail market

- Take into account factors affecting organized retail business

- Facing challenges in organized retail sector

\section{Research Methodology}

Research methodology based is on two factors: survey Research and Interview method. Survey research and interview were applied in this particular research methodology to gather primary and secondary data in order to critically analyze organized retail in KSA as well as challenges from the socio-economic and socio- cultural factors - give shapes to a new retail global companies establishing in KSA. Data and information are gathered to focus the objective of present study as titled organized retailing in context with amalgamation firms in KSA. The method, which is applied here for data collection is survey research and interview method. The questionnaire is designed and pre-tasted through personal interview with supermarket hypermarket, malls managers and retail outlet owners.

\section{Discussion}

It is worth mentioning that the data mentioned in this dissertation has been gathered from 150 retailers of leading cities like Riyadh, Jeddah, Makah, Jizan and Taif by virtue of a self structured questionnaire. What is important to mention is that stratified random sampling has been applied. Sawpna Pardhan (2006) has considerably studied Retail Management p $32^{20}$ mentioned. There are many factors, which enhance

20 Sawpna Pardhan 2006 Retail Management p-32 
organize retailing in KSA for example:

\subsection{Socio-Economic Factor}

Socio- economic factors play a vital role in organized retailing particularly in Saudi Arabia. As per capita income in this universe is better than GCC countries, KSA has large number of middle class consumers, which gives boost to retail sales and steady growth to the GDP. Therefore, socioeconomic factors play an important role in enhancing retail sales. Customers belonging to different income group have different economic propensity in organized retail suit to their choice and options for commodities they opt for.

\subsection{Changing Income Profile}

As economic capability of KSA, the changing income profile has comparatively improved and grownup in the global market. At the same time, it gives further boost to organize retailing marketing. What is worth mentioning is that middle class customers have become the backbone of the organized retailing. It can be evident from the changing income profile data, middle class youth have larger economic propensity of giving boost to organized retailing. Furthermore, there are other five factors to boost the organized retailing in respect of changing and varying income profile. It is pertinent to mention here that customers or buyers are below the age of 40 years, who have larger propensity for buying goods by virtue of organize retailing. It is worth mentioning that college going students: male and female as well as customers belonging to 40 years of age quickly respond to sale and purchase on the organized retailing. What is important is that such group of customers has rather a fixed income level; they, therefore, prefer to opt for organized retailing considerably.

\subsection{Role of Women}

Role of women in organized retaining in KSA is getting relevant considerably. According to employment plan $2014^{21}$ population, working women have grown up considerably. What is important to mention is that 12.4 million female in KSA out of which $8.8 \mathrm{mn}$ are of working age. Women participation in work force has been found rather low by international standard exceeding from the current $20.1 \%$ out of which male participation rate is $77 \%$ to $43 \%$ average of GCC. A.T Kearny 2012 rightly mentioned in his report entitled as "Global Retail Expansion keeps on Moving" to that of Saudi Arabia stands 8th retail Index.

The Minister of Labor has already planned to recruit more women workforce to increase the share of women force in the job market. Some Saudi companies are also interested in enhancing and increasing more job opportunities. Those companies, which are interested in enhancing women workforce are Al- Marai Milk Company, Gulf Catering, Western Bakeries Ltd, Sadafco and Unileaver are recruiting

21The Retail Talent Index 2014

Sources: A. T Kearney Analysis 2012 women employees in different capacity which suits to women. What is the most important for demand side initiative is "female employment in retail sector to fill up the gap between the female workforce and male workforce. Women workforce are made part of job market that can be in a better way to read, locate and communicate the priorities of women buyers. The women workforce are made part of the workforce emerges in a twofold way. There are women employees of a higher and larger status who are assigned to delegate duty, task and workforce to the employees at middle level capacity, creating a more congenial environment for delegation of duties.

Table 5. The Retail Talent Index.

\begin{tabular}{|c|c|c|c|c|c|}
\hline $\begin{array}{l}\text { Rank } \\
2012\end{array}$ & Country & $\begin{array}{l}\text { Talent } \\
\text { Availability }\end{array}$ & $\begin{array}{l}\text { Labor } \\
\text { Regulation } \\
20 \%\end{array}$ & $\begin{array}{l}\text { Labor } \\
\text { Cost } \\
40 \% \\
\end{array}$ & Score \\
\hline 1 & Malaysia & 62.8 & 77.9 & 85.7 & 75.0 \\
\hline 2 & China & 56.5 & 71.3 & 79.0 & 68.5 \\
\hline 3 & Chile & 66.7 & 56.7 & 68.5 & 65.4 \\
\hline 4 & Indonesia & 51.0 & 55. & 84.5 & 65.4 \\
\hline 5 & Azerbaijan & 42.1 & 95.9 & 72.5 & 65.0 \\
\hline 6 & India & 48.5 & 64.2 & 75.6 & 62.5 \\
\hline 7 & Lebanon & 56.1 & 74.8 & 61.4 & 62.0 \\
\hline 8 & $\begin{array}{l}\text { Saudi } \\
\text { Arabia }\end{array}$ & 57.4 & 93.5 & 50.8 & 61.9 \\
\hline 9 & UAE & 67.7 & 94.2 & 39.6 & 61.8 \\
\hline 10 & Sri Lanka & 48.7 & 49.4 & 80.5 & 61.5 \\
\hline
\end{tabular}

\subsection{Varying Age Groups Customer in KSA Context}

Varying age factor is no less important in a universe in which organized retailing has a larger chunk of enhancing customer base. One of the major reasons behind change in retail sector is population that is younger population of KSA. What is striking is that retail sector in KSA basically from young population, increasing disposable income, as well as enhancement in consumer motivation as varying age factor from rather different propensity of retail sector. The organized retailing is more competitive in the international arena. Therefore, it can be argued and concluded that growing population is the basic drivers and factors for different retail sector in KSA. What is worth pointing out is that a consumer of aged up to 24 is one-third of total population of KSA.

\subsection{The Changes in Banking System}

With growing network of education spreading in KSA Saudi, customers have simultaneously responded to the new demands of categories and systems of transactions of money in organized retail sectors. It can be seen that the Saudi population has grown up to the great extent applies various method of payments viz. mobile banking, internet banking, credit Card and ATM as well as traditional banking. It is worth mentioning that credit card and internet banking have been found more comprehensive and friendly using.

It is worth mentioning that the data of organized retailing presented by Cronbach's alpha has been found to be 0.935 . 
The descriptive statistics have been applied to study organized retailing in KSA. The present study, "organized retailing in Saudi Arabia follows the descriptive statistics namely mean and standard deviation for analyzing those major drivers which multiplies and enhances retail business in KSA.

Table 6. Major Growth Driver of Organized Retailing.

\begin{tabular}{|c|c|c|c|c|}
\hline S. No & Growth Drivers & Mean & Std Deviation & Rank \\
\hline 1 & Increase in FDI & 3.80 & 1.13 & 4 \\
\hline 2 & $\begin{array}{l}\text { Expansion of Retail } \\
\text { Industry }\end{array}$ & 3.61 & 0.98 & 9 \\
\hline 3 & $\begin{array}{l}\text { High growth in real } \\
\text { estate }\end{array}$ & 3.76 & 0.99 & 5 \\
\hline 4 & $\begin{array}{l}\text { Increase in disposable } \\
\text { Income }\end{array}$ & 3.64 & 0.77 & 8 \\
\hline 5 & $\begin{array}{l}\text { Expansion of } \\
\text { Urbanization }\end{array}$ & 3.72 & 0.89 & 7 \\
\hline 6 & Infrastructure & 3.96 & 0.98 & 1 \\
\hline 7 & Demography & 3.92 & 1.15 & 3 \\
\hline 8 & Global brands & 3.9 & 1.08 & 10 \\
\hline 9 & Economic Growth & 3.89 & 1.15 & 2 \\
\hline
\end{tabular}

The table mentioned above indicates the major growth drivers, which affects organized retail in KSA. It is worth mentioning that the data mentioned in this dissertation have been gathered from retailers operative in Makah, Jeddah, Riyadh, Dammam and Jizan. A reliability test, on the basis of Cronbach's Alpha is used to test the each internal consistency and the results are positive. The date mentioned in present dissertation point out that consumers are responding to the new emerging trends of retail sector.

The present dissertation, therefore, intends to locate leading drivers of retail sectors. The present research work at the same time examines infrastructures economic growth and changing demographics from retailer's stand point of view. It is important to mention that the basic three factorsinfrastructure, economic growth and changing demographics act as significant drivers of retail corresponding to the upward trend of FDI and real-estate. Retailers' think-tank ,therefore, need to give more priority to retail ancillary market and respond to international products and brands. In other words, retail growth drivers need to be adjusted with international brands. Retail ancillary needs to be made more comprehensive. Therefore, there should be a correlation between retail ancillary and incoming availability of international brandswould ultimately act as a retail growth driver. What is important is that the retail ancillary market can't afford to deviate from the dictate off international brands.

\section{Challenges}

According to report published in Economic Times India as dated $16^{\text {th }}$ Feb. 2015, DUBAI: Saudi Arabia's nonhydrocarbon sector has maintained optimism level in first quarter of 2015 compared to the last quarter as well as last year, a new survey has said.

According to Dun \& Bradstreet South Asia Middle East
Ltd (D\&B) survey for Saudi Arabia, ${ }^{22}$ the hydrocarbon sector amalgamated Business Optimism Index (BOI) is recorded down sharply by slow opportunity for value and productivity; at 16 points, the index has shed 18 points from last quarter and is 34 points lower compared to last year. According to the survey, 59 per cent of non-hydrocarbon sector firms and 65 per cent of hydrocarbon sector firms do not foresee any hindrances to their business operations in Q1, 2015; competition is cited as the foremost concern across all sectors. The investment outlook has moderated; 47 per cent of non-hydrocarbon firms will invest in expansion activities in Q1, 2015 versus 53 per cent in Q4, 2014.

Sharihan Almanzalawi ${ }^{23}$ Economist of the National Commercial Bank, said: "While the KSA' hydrocarbon sector BOI is weighed sharply to 16 points, attributed to the free fall of oil prices, the KSA's non-hydrocarbon sector BOI maintains its optimism level, registering 48 points in first quarter of 2015 .

Table 7. Share of Hydrocarbon and Non-hydrocarbon Sector in Nominal GDP 2013.

\begin{tabular}{lll}
\hline Countries & Hydrocarbon & Non-hydrocarbon \\
\hline UAE & $33 \%$ & $67 \%$ \\
Saudi Arabia & $47 \%$ & $53 \%$ \\
Qatar & $54 \%$ & $46 \%$ \\
Kuwait & $64 \%$ & $36 \%$ \\
Bahrain & $28 \%$ & $72 \%$ \\
Oman & $49 \%$ & $51 \%$ \\
\hline
\end{tabular}

Source: Alkhabeer Capital, August 2014

Frost Sullivan ${ }^{24}$ emphasized that another challenge KSA is facing due to scarcity of human resources owing to high attrition rates. In addition, high rental rates in the top-tier malls deter the growth of the retail market. Availability of substitute products and expensive e-commerce transactions due to high bank rate are some of the other deterrents faced by the retail sector in the KSA.

\section{Outcome Analysis}

The Saudi Retail landscape with globalization trend has undergone a sea change. Reasonably Baquala has been replaced and competed by new emerging trends of supermarket, hypermarket and malls. Such global innovations have become a source of attraction for the new Saudi buyers. It can be realized from the new trends in KSA that there is a competitive sprit among Saudi buyers to be different from those of middle-east cities like Bahrain, Qatar, Dubai and UAE. The data gathered from organized retailing in KSA intend to acquire maximum of market share. Mall entrepreneur along with their management necessarily realized relevance of restructure, innovation and

22Dun \& Bradstreet South Asia Middle East Ltd (D\&B) survey for Saudi Arabia, 23Sharihan Almanzalawi,Economist of the National Commercial Bank

24http://ww2.frost.com/news/press-releases/retail-industry-kingdom-saudi-arabiabooster-shots-frost-sullivan-assesses-factors-fuelling-growth/ 
diversification of products in terms of different category and class of buyers. Thus strategy adopts for organized retailing in KSA, the outcome analysis of the present retail universe is supposed to earn a higher financial as data mentioned in table 6 but the actual challenge before Saudiazation is how to retain its workforce providing highest standard in the Saudi retail market. From this aspect Saudiazation has to be more competitive and rather comprehensive in order to compete and upturn competitors share and above all in the global market. As a result a new business class has emerged particularly settled for meeting with the requirement of domestic business getting thus diversified in organized retailing, which can be further adjusted with worldwide standard. What needs to be emphasized is that there should necessarily be balance and compromise between investment and planning with a view to channelize and introduce and replenish the global market with new emerging Saudi workforce. Therefore, the following points mentioned as below need to be considered:

1. Impact of globalization on the KSA market

2. Emergence of new Saudi workforce: their priorities and preferences

3. With the emergence new inbuilt class and category of Saudi buyers, can be estimated and understood their own demand requirement consumption of goods

4. With Saudiazation, there will necessarily more income on account of its KSA workforce

5. That there should be a co-relation between the percentage of removal of expatriate and the new emerging workforce.

There is a tremendous impact of emergence of Saudi society by virtue of which in coming global factors. As a result of which internet, online retailing and others moderns system and techniques of communication have become popular in middle east and KSA. Online retailing is a new means of sale and retail purchasing of products. There are necessarily many advantages of online retailing for examples online retailing helps retailers to reduce rent of warehouse, office and remuneration spent on staff improving margin and offering considerable discount to customers. In addition, online retail getting popular day-by-day among women and single men due to kingdom's social structure. Taking into account the increase in purchasing power and rising income level of women in KSA are getting more inclined on online shopping. Online retailing, thus, is preferably opted by women and single men. It is worth mentioning that about 12 million tourists pay visit to Saudi Arabia every year: a number of retail entities thus have risen in the region. It can thus be seen that Makkah \& Madinah single handedly cover $6 \%$ of total GLA. The KSA GDP has extensively extended from 1970 - 2012. The $\mathrm{IMF}^{25}$ on the other hand expects a comprehensive GDP growth in order to retain it $4.2 \%$ during right from 2013 - 2018. KSA has extensively neutralized its oil revenue to diversify into non oil sectors.

According to IMF KSA population is supposed to increase

25 IMF Report
2010-2015 CAGR of $1.4 \%$ which is further supposed to reach which at 29.02 million in 2015". Taking into account the above inference, it is evident that the KSA government invests in infrastructure i.e. plans to invest SR 250 billion over the next 10 years. Therefore, the KSA government pays comprehensive salary to its employees working in public sector. As per report submitted by IMF per capita GDP is supposed to reach $\$ 85958$ by 2015 . Therefore, findings and inference of the present dissertation is suggestive of the basic fact that organized retailing in Saudi Arabia and growth drivers applied in organized retailing come closer to fulfilling the requirement of growing demand and emerging Saudiazation.

Presently, KSA is facing a great challenge due to shortages of skilled manpower of outstanding to elevated attrition rates in Saudi Arabian retail sector. In addition, high rental rates in the top-tier malls discourage the development of the retail market. Availability of alternative products and high-priced e-commerce dealings are some of the other deterrents faced challenges by the organized retail sector in the Kingdom of Saudi Arabia.

\section{Conclusion}

There is a directly proportional relation between the consumers dwelling in KSA and organized and unorganized retailing in Saudi Arabian context. The data mentioned above realistically reflect a slight variation in price of commodities of a sizeable variation in sales \& purchase of a particular commodities.

Stephen R. Covey rightly defined in his book "The 7 Habits of Highly Effective People" the concept of effective leadership that there are three kinds of people in our society i.e. dependent, independent and interdependent. He speaks further interdependent are the real leaders who believe in "Synergy". It is worth mentioning that synergy stands for amalgamation of two energies that is essentially needed to adapt, to sustain and to maintain the growth in present order of stiff competition.

The study reaches out the understanding that the business imperatives drove the giant corporate like McDonald, KFC, Domino's Pizza, Starbucks, Pepsi, Coca Cola and Carrefour etc. to realize the importance of small Baquala (small store) and other unorganized small firms.

The present business practices reflect that big firms are compelled to realize that there is a need to develop a relationship with small firms either organized or unorganized sector that is why all the big companies are trying to develop the business association with these small fragmented business unorganized entities. The baqualas (small grocery) still own much of the market, so there is big scope of development of organize retailing. New entries, expansion and amalgamation of companies in 2015- 2016 as part of Saudi Arabia retail attraction. IKEA is going to be open four new stores in 2016. Alhokair Fashion Retail plans to grow the Mark and Spencer store portfolio in KSA. Al-Medina group Chain of Supermarket already entered in Riyadh and 
one more store will be open in Jeddah 2016. Kcal Fast food chain is also ready to launch in Saudi Arabia.

That shows that to unfold the untapped potential rooted in traditional markets cannot be penetrated unless and until local unorganized players in market is synergized into an amalgamation to outreach the consumers.

There is a need to revisit the potential of unorganized firms and evolve a better association with sharing the success, profit, responsibility and ownership in order to establish the business relationship and to use the best of their energies as well as to capacitate these unorganized firms like Baquala to enjoy the profit and prestige of organized industry.

The key success of the organized retailing needs setting up direct market coverage plan for product distribution keeping in view their product availability and visibility in the high competitive market. It is helpful by implementing direct market coverage distribution operation that make possible long-term growth as well as raising solid foundation of profit margins. Finally it can be suggested that the organized retail sector will be the major beneficiary of the growth in the KSA retail sector, as customer preferences shift toward smaller firms to large firms like supermarkets and hypermarkets.

\section{References}

[1] The 2015 Global -Retail Development Index ${ }^{\mathrm{TM}}$.

[2] Agamdi, A 2008, 'e-Commerce Implementation Challenges and Success Factors in the Kingdom of Saudi Arabia', paper presented to 19th National Computer Conference: the digital economy and ICT industry, Riyadh, 1-5 Nov.

[3] Barry Berman \& Joel R. Evans Retail Management edition (2008) PHI learning P. ltd.

[4] Gilbert David, Retail Marketing Management (2003) Pearson Education second Ed.

[5] Pradhan Swapna Retailing Management (Text and Cases) 3rd Edition, McGraw Hill H Ed.

[6] Minakshi N \& Kumar Arun, Marketing in Action, I.M. Technology, New Delhi.

[7] David Jobber \& Geoff Lancaster, Selling and sales management (9th ed) Pearson.

[8] Loudon, L. D., \& Bitta, D. J. A. (1994). Consumer behavior 4th ed. McGraw Hill, Inc.

[9] Paul Brittain \& Roger Cox, Retailing An Introduction, Prentice Hall 5th Ed (2010).

[10] Donald R. Cooper S. Schildler Business Research Method (2003) Tata McGraw Hill.

[11] Wile man, A and Jary, M. (1997) Retail Power Plays. London: Macmillan.

[12] Mills, K. H., Paul, J.E. \& Moorman, K.B., (1995), Applied visual merchandising (3rd ed.), Englewood Cliffs, New Jersey: Prentice-Hall.

[13] Quartier K, Vanrie J \& Van Cleempoel K, (2009), “The interaction between interpreted space, mood and behavior in retail environments: a conceptual research model", IASDR09 'Design: Rigor and relevance, pp 2-4.

[14] Matthew L. Tullman \& Clark K. Rose, (2004), "Revitalizing Visual Merchandising- Restoring balance to retail environment entails engaging all five senses", 1-2.

[15] Darden, W.R., Erdem, O. \& Darden, D.K. (1983), “A comparison and test of three casual models of patronage intentions", Patronage Behavior and Retail Management, New York, NY: North Holland.

[16] Jiyeon Kim, (2003), "College Students' Apparel Impulse Buying Behavior in Relation to Visual Merchandising", pp 45-49.

[17] Omar, O. (1999), Retail Marketing, Pitman Publishing, London.

[18] Farfan, B. (2014). About.com. Retrieved from 2014 US Retail Industry Overview- Info, Facts, Research, Data, Trivia: $\mathrm{http}: / /$ retailindustry.about.com.

[19] McGoldrick, P. (1990), Retail Marketing, McGraw-Hill, Maidenhead.

[20] McGoldrick, P. (2002), Retail Marketing (2nd Edition), McGraw-Hill, Maidenhead.

[21] Kotler, P. (1974), “Atmospherics as a marketing tool” Journal of Retailing, Vol.49, 48-64.

[22] AT Kearney (2014), “The Global Retail Development Index: Lessons Learned from Decade of Retail Expansion”, 2014.

[23] Rahman M.N (2012) International Journal of Scientific \& Engineering Research, France, Volume 3, Issue 11, November-2012 1 ISSN 2229-5518.

[24] Rahman M.N (2014) International Journal and Economic 2014, Development Volume 2 No 1, March 2014, ISSN No 2051-848X UK, page 102-113.

[25] Deloitte. (2012). middle east retailers record strongest growth as global sales rise 5\% Retrieved from Business Intelligence Middle East.

[26] Gabriel, C., Gregorio, A. D., \& Nader, K. (2011). Retail Analytics The Route to Improved [1] Profitability for Middle East Retailers. Booz \& Company.

[27] GCC retail sector robust. (2013, January). Retrieved from Retail ME: http://www.imagesretailme.com/ImagesRetailME-Articles.aspx?ArticleId=166.

[28] Harris, E. (2012). The Retail International Programme Expansion Index.

[29] Jones, R. (2012). Middle East to set pace on luxury. Retrieved from The National: http://www.thenational.ae/business/industryinsights/retail/middle-east-to-set-pace-on-luxury.

[30] http://www.bi-e.com/main.php?id=56440\&t=1.

[31] Dr. Shahid Akhter, Iftekhar Equbal (2012), Organized Retailing In India -Challenges And Opportunities, International Journal Of Multidisciplinary Research Vol.2 Issue 1.

[32] http://www.aljaziracapital.com.sa/report_file/ess/SEC-34.pdf. 
[33] http://ww2.frost.com/news/press-releases/retail-industrykingdom-saudi-arabia-booster-shots-frost-sullivan-assessesfactors-fuelling-growth/.

[34] http://www.nielsen.com/sa/en/insights/news/2015/regulations- are-reconfiguring-retail- in-saudi-arabia.html

[35] https://www.atkearney.com/consumer-products-retail/globalretail-development-index/2015.

[36] http://www.euromonitor.com/retailing-in-saudi-arabia/report. 